\title{
Ensuring Protection against Caste Discrimination in Britain: \\ Should the Equality Act 2010 be extended?
}

\author{
Annapurna Waughray and Meena Dhanda*
}

\begin{abstract}
:
Section 97 of the Enterprise and Regulatory Reform Act 2013 requires the addition of caste to the Equality Act 2010 by secondary legislation as 'an aspect of' the protected characteristic of race; but despite being mandated, no secondary legislation has been introduced and the addition of caste remains contested by some academics, civil society organisations, and politicians who question the adequacy of any definition of caste, the estimates of the extent of caste discrimination, and whether legal protection against caste discrimination already exists under the Equality Act. In this article we assess whether legal protection against caste discrimination is now assured following the Employment Tribunal judgment in September 2015 in Tirkey $v$ Chandhok \& Anor which held that discrimination on grounds of caste, depending on the facts, might be capable of falling within the scope of race as currently defined in the Equality Act. We argue that Tirkey is significant but not decisive and that it remains open to government to extend the Equality Act to cover caste.
\end{abstract}

Keywords: caste, caste discrimination, Equality Act 2010, discrimination, discrimination law, equality law, race, ethnic origins, Jati, Adivasi, Tirkey $v$ Chandhok

\section{Introduction}

In April 2010 there was mixed reaction - jubilation for some, dismay for others - at the inclusion of s. 9(5)(a) in the Equality Act 2010 (EA), an enabling provision which provided a power for caste to be added in the future, by secondary legislation, to s. 9(1) of the Act as 'an aspect of' the protected characteristic of race, defined in the legislation as including colour, nationality, and ethnic or national origins. In April 2013, s. 97 of the Enterprise and Regulatory Reform Act 2013 (ERRA) converted the 'caste power' in EA s. 9(5)(a) into a duty, thereby requiring government to introduce secondary legislation to add caste to race although it gave no indication as to how this was to be done. ${ }^{1}$ In July 2013 the coalition government published a timetable for the introduction of the secondary legislation which included two public consultations on the proposed legislation, going up to and beyond the May 2015 General Election. ${ }^{2}$ A year later, in July 2014, with no consultation document 
unveiled, the Government was questioned in Parliament about the delay. The Parliamentary Under-Secretary of State for Women and Equalities, Helen Grant, explained that the UK's Equality and Human Rights Commission (EHRC) had originally intended to commission research to establish "baseline data" inter alia on the scale of caste discrimination in the UK, but had decided that such research might be intrusive and damaging to community relations. The Government was therefore conducting a study on the feasibility of carrying out such research; ${ }^{3}$ but as at the time of writing this study had not been published. ${ }^{4}$ No secondary legislation was introduced by the then Conservative - Lib-Dem coalition government (20102015) and the Conservative government which came to power in May 2015 has not formally announced whether it intends to introduce legislation or not. In coalition the Conservatives were opposed to extending discrimination legislation to cover caste, and conceded to s. 97 of the ERRA only because the government suffered a last-minute defeat on the issue in the House of Lords (Waughray, 2014). ${ }^{5}$ At present, over five and a half years since the enactment of the EA there is still no statutory prohibition of caste discrimination in British discrimination law, and despite being mandated in 2013, the addition of caste in the EA remains highly contested.

The existence of, first, a statutory power and subsequently a statutory duty to make caste an aspect of race in the EA has raised the visibility of caste as a ground of discrimination and has given rise on the one hand to an expectation of legal protection against caste discrimination, on the other hand to vocal opposition to the principle of introducing a statutory prohibition of caste discrimination in the UK. Against this backdrop, and in the absence of an explicit statutory prohibition of such discrimination, it was inevitable that claimants would seek to persuade the courts that caste is already covered by the EA under one or more existing protected characteristics. Since the EA came into force, UK Employment Tribunals have been asked to determine in two cases whether caste is or could be subsumed within race as currently defined, specifically within the concept of ethnic origins. In Naveed $v$ Aslam in 2012 the Employment Tribunal held that it could not; ${ }^{6}$ but in Tirkey $v$ Chandhok \& Anor in September 2015 the Employment Tribunal held that the claimant was the victim of unlawful harassment on grounds of race and that her treatment was because of her ethnic origins, defined by reference to her inherited position in society (in whole or in part on the basis of her caste), her birth, and her upbringing. ${ }^{7}$ Tirkey is the first UK case in which caste has formed an element of a successful race discrimination claim, and the judgment was immediately hailed in the media as a legal landmark. ${ }^{8}$ However, it does not resolve the question of whether in principle caste falls within the scope of race in the EA as currently worded. Supporters of caste discrimination legislation argue that the outcome in Tirkey should not be used as an excuse to further delay or abandon introducing 
a statutory prohibition of caste discrimination as mandated by parliament. Opponents of legislation, including the 2010-15 coalition government and the Conservative government of David Cameron, have argued that there is insufficient evidence of caste discrimination in the UK to justify legislation; that introducing statutory protection against caste discrimination is socially divisive and will damage community cohesion; and that caste is already covered within the scope of existing discrimination legislation, as shown by Tirkey. Organisations such as the Alliance of Hindu Organisations and the National Council of Hindu Temples UK further argue that the demand for caste discrimination legislation, and the outcome in Tirkey, reflect Christian evangelical denigration of what they have begun to term the global 'Dharmic community' (Hindus, Sikhs and Jains), ${ }^{9}$ a phenomenon allegedly rooted in colonialism whose perpetrators have 'created' the 'caste system' (Shah, 2014) as representing the immorality and degeneracy, in their eyes, of Indic religions and cultures. ${ }^{10}$

In this article we assess the current position vis a vis the legal regulation of caste discrimination. We ask whether legal protection against caste discrimination is now assured by the Tirkey judgment, or whether irrespective of the outcome in Tirkey the EA should be extended to cover caste. We argue that, notwithstanding the prevarication of successive governments on the introduction of caste legislation, an important impact of the change made in April 2013 to the EA was the creation of the climate in which the Tirkey case could be brought. We explain the political and legal background to the inclusion of the 'caste power' in EA s. 9(5)(a) and the circumstances which resulted in the power being converted, in 2013, into a duty to add caste; we introduce the concepts of caste and caste discrimination in the UK context; we take stock of legal developments since 2010, including an analysis and evaluation of the Tirkey judgment; and we conclude by reflecting on the alternative options available to the government to ensure legal protection against caste discrimination in accordance with its international law obligations.

\section{Caste in the Equality Act 2010: Legal and Political Context ${ }^{11}$}

The movement to secure legal protection against caste discrimination in the UK gained momentum in the early 2000s against the backdrop of growing international awareness of discrimination on grounds of caste, coupled with frustration among Dalits (formerly known as 'Untouchables') at the perceived lack of legal redress in Britain for such discrimination. ${ }^{12}$ Caste is a prohibited ground of discrimination in the legal orders of a number of States, including India, Pakistan, Bangladesh, Sri Lanka, Nepal, Burkina Faso, and Mauritius, but the term caste is not found in any international human rights instrument, and until its appearance in EA s. 9(5)(a) the term did not appear in UK discrimination law. ${ }^{13}$ In India, caste discrimination (alongside discrimination on grounds of religion, race, sex, and place of 
birth) is prohibited in the 1950 Constitution of India (COI), drafted following independence in 1947. ${ }^{14}$ The COI also abolishes 'Untouchability' and criminalises its practice, ${ }^{15}$ and provides for affirmative action measures for Scheduled Castes (the official administrative term for exUntouchables) and Scheduled Tribes (the administrative term for tribal peoples or 'Adivasis') in the form of quotas in higher education, public sector and government employment, and political representation. ${ }^{16}$ India also has legislation in place prohibiting hate crimes against Scheduled Castes (although unlike the UK, India lacks civil anti-discrimination legislation). The same legislation prohibits hate crime against Scheduled Tribes (Adivasis). ${ }^{17}$ It was assumed that as a result of these measures, discrimination, inequality, and violence on grounds of caste would be quickly eradicated. This did not happen, and by the early 1980s Indian activists had begun to look beyond India, to UN fora and non-governmental organisations, for help in challenging the abysmal social and economic conditions and discrimination faced by many Dalits (Bob, 2007). As a result of their efforts, by the mid1990s the UN human rights system had begun to take cognisance of caste discrimination and oppression as a human rights issue.

The response came from two UN bodies in particular: the UN Committee on the Elimination of Racial Discrimination or CERD, the monitoring body of the International Convention on the Elimination of All Forms of Racial Discrimination 1965 (ICERD, to which India and the UK have been parties since 1968 and 1969 respectively); and the former UN Sub-Commission on the Promotion and Protection of Human Rights (now the Human Rights Council Advisory Committee). Racial discrimination is defined in Article 1(1) of ICERD as discrimination on grounds of race, colour, descent, national origins, and ethnic origins. In 1996 CERD affirmed that caste is captured by Article $1(1)$, within the sub-category of descent. ${ }^{18}$ CERD's interpretation of descent as including caste was reiterated in 2002 in its General Recommendation No. 29 in which it affirmed that discrimination based on descent 'includes discrimination against members of communities based on forms of social stratification such as caste and analogous systems of inherited status which nullify or impair their equal enjoyment of human rights.' 19 In the meantime, in 2000 the then UN Sub-Commission on the Promotion and Protection of Human Rights declared discrimination based on work and descent - a new legal category which includes but is wider than discrimination based on caste - to be a violation of international human rights law, commissioning what would be the first of three experts' reports on the phenomenon. ${ }^{20}$ Since 2002 CERD has enquired about discrimination based on descent, including caste and 'analogous systems of inherited status', in a number of States including India, Japan, Nepal, and the UK. CERD's interpretation of descent as including caste is rejected by India and Japan - although not by the UK or Nepal. The UK's response to recommendations by CERD in 2003 and again in 
2011 to introduce domestic legislation to address descent-based discrimination including discrimination on grounds of caste, rather than challenge CERD's interpretation of descent, has been to argue that the UK does not have a problem of caste discrimination requiring a legislative solution (Waughray, 2014).

In Britain there has been a Dalit presence since the 1960s. ${ }^{21}$ Academic studies show that as a 'minority within a minority' Dalits in Britain have faced not only 'external' discrimination, as South Asians, by the majority community but also 'internal' discrimination on grounds of caste from fellow South Asians. ${ }^{22}$ The EA now provides comprehensive protection against discrimination on nine grounds, or protected characteristics (age, disability, gender reassignment, marriage and civil partnership, pregnancy and maternity, race, religion or belief, sex, and sexual orientation); but it has been argued that pragmatism rather than principle continues to drive decisions as to whether the legislation should be extended (O'Cinneide and Lui, 2015). The absence of the term 'caste' in British discrimination law prior to the EA meant that there was no cause of action for caste discrimination unless claimants could successfully argue that caste was subsumed within an existing protected characteristic such as race or, after 2003, religion or belief. This remains the case given that caste has not yet been explicitly added to the prohibited grounds of discrimination, or protected characteristics, in the EA.

In 2000, a UK-based Dalit non-governmental organisation (NGO), Voice of Dalit International, organised an International Conference on Dalit Human Rights in London which called for caste be added to UK discrimination law, demanding that 'laws which address discrimination based on racism should take cognisance of casteism and place it on a par with racism' (Muman, 2000). The legislation in force at that time, the Race Relations Act 1976 (RRA), prohibited discrimination on racial grounds, meaning colour, race, nationality or ethnic or national origins or by reference to membership of a racial group defined by the same grounds. These terms were not defined in the legislation; instead, their meaning was developed through case law. Dalit NGOs argued that there was a gap in the existing law because caste could not be captured by race or ethnic origins given that perpetrators and victims of caste discrimination often shared the same race and/or ethnic origins as then understood. In 2005 the then Labour government announced its intention to introduce a new, single, Equality Act. Dalit NGOs seized this opportunity to campaign for the addition of caste to the legislation, submitting responses to the government's consultation process, collecting and publishing evidence of caste discrimination, organising conferences on caste and British equality law, and lobbying parliamentarians. ${ }^{23}$ This activity was mirrored by those opposed to the inclusion of caste in the new legislation, primarily South Asian religious and 
civil society organisations, who either disputed the existence of caste discrimination altogether or argued that there was no such discrimination in spheres regulated by discrimination law (Waughray, 2009).

When the Equality Bill was published in April 2009, caste was not included. The government's primary reason was that there was insufficient evidence of a problem requiring a legislative solution (for example discrimination occurring in legally-regulated fields); a secondary reason was that caste could already be covered by existing protected characteristics (Waughray, 2009; Waughray, 2013). Advocates of caste discrimination legislation argued not only that such discrimination did occur in both regulated and unregulated spheres, but that it could only partially be captured by existing legislation on race and religion or belief discrimination, and that to establish in the courts that discrimination on grounds of caste is covered by existing legislation would be an extremely costly and uncertain process (Waughray, 2009; Waughray, 2014; Dhanda et al, 2014a). Between April 2009 when the Bill was published and April 2010 when the EA was adopted, caste was transformed from a legally and politically invisible issue to a visible issue, largely due to the efforts of Dalit organisations for whom the possibility of securing legal protection against caste discrimination in the new legislation was perceived as a once-in-a-lifetime opportunity. The question for legislators - indeed, for all - was whether caste could fall within the ambit of an existing ground of discrimination. If it could, did this therefore mean that a statutory prohibition of caste discrimination was unnecessary? If it could not, did this mean that caste should be introduced as a new, distinct, ground? (Waughray, 2009). RRA case law on 'racial grounds' had focussed on the meaning of ethnic origins rather than race as such. The leading case on ethnic origins, Mandla $v$ Dowell Lee (1983), established that 'ethnic origins' or membership of an ethnic group is not synonymous with 'race' in a narrow, biological sense but is to be construed 'relatively widely' in a broad cultural/historic sense. For a group to constitute an ethnic group, it must regard itself and be regarded by others as a distinct community by virtue of certain characteristics, two of which are essential: a distinct, living and long shared history as a group; and a cultural tradition of its own, including family and social customs, often but not necessarily associated with religious observance. ${ }^{24}$ On this basis Sikhs, Jews, Romani gypsies, and Irish travellers have been held to be ethnic groups; but Rastafarians and Muslims have not. ${ }^{25}$

Whether and how the Mandla definition could apply to caste groups was unclear. It was by attempting to address this question from the mid-2000s onwards that one of the authors first drew attention to the challenge of capturing caste in domestic discrimination law. ${ }^{26}$ It was inevitable, given the growing awareness of caste and caste discrimination in the UK, that 
arguments that 'ethnic origins' include caste would eventually come before the courts. In 2009 the UK Supreme Court in $R$ (E) v JFS had held that 'ethnic origins' in domestic law includes the notions of a person's birth, lineage, descent, or ancestry - descent being the category in the ICERD definition of racial discrimination which has been affirmed by CERD as including caste (see above), although it has never been a category in domestic race discrimination legislation. ${ }^{27}$ This led successive governments to argue that caste could already be covered by race as currently defined in the EA by virtue of the descent aspect of ethnic origins; but as has been argued elsewhere, 'in order to construe caste as part of race in domestic law following the JFS route, a three-fold interpretive leap had to be made; caste must be viewed as part of descent, itself part of ethnic origins, which in turn is a sub-set of race' (Dhanda et al., 2014a: 15).

The enabling provision permitting caste to be added at a future date 'as an aspect of' race came to be included in the EA as the result of a last-minute House of Lords amendment to the Bill, which was unopposed by the then Labour government due to the need to reach agreement on the terms of the Bill before the end of the Parliamentary session. Its inclusion was to prove critical to subsequent developments, but it was not the immediate prohibition of caste discrimination that Dalit organisations had sought, and it located caste within the protected characteristic of race rather than listing it as a separate characteristic. On the other hand, its inclusion pursuant to well-publicised debates in Parliament contributed to a legal climate which was receptive to the pleading of claims of caste discrimination subsequently. By this time, reports by researchers commissioned by Dalit NGOs and community organisations detailing examples of caste-related harassment, humiliation and other discriminatory behaviour had emerged (Mahimaidass and Sadana (DSN), 2006; ACDA, 2009). However, these reports were criticised by sceptics and opponents of legislation as lacking independence and objectivity. ${ }^{28}$ In March 2010 the outgoing Labour government commissioned research on caste discrimination from the National Institute of Economic and Social Research (NIESR). Due to its small scale, its evidence was deemed unconvincing by some and insufficient by others, ${ }^{29}$ but it confirmed the existence of caste in Great Britain as well as evidence suggesting the occurrence of discrimination based on caste in regulated fields (NIESR Report: Metcalfe, 2010). In September 2013 the EHRC, at the request of government, commissioned independent research from a team of academics (including the present authors) to help inform the introduction of the statutory prohibition of caste discrimination pursuant to the requirement in the ERRA. As part of the EHRC Caste in Britain research, two events were organised: an experts' seminar and a workshop for extended dialogue between three sets of 'stakeholders': representatives of those opposed to legislation, those in support, and those responsible for implementing it; and two research 
reports were published. The gap in perception between the first two sets of stakeholders was replayed in the stakeholders' workshop conducted as a part of the EHRC research (Dhanda et al 2014b). The widest divergence was in the written answers to one specific question in the statements submitted by stakeholders: 'Have you directly or indirectly come across any instances of discrimination, harassment or victimisation related to the issue of caste in the UK? Please give examples if you can.' Opponents of legislation uniformly answered 'no', whilst supporters of legislation gave examples of perceived caste discrimination. Following the workshop, the Alliance of Hindu Organisations (AHO), one of the main opponents of legislation, did shift its position to accept the existence of 'pockets of discrimination'. ${ }^{30}$

To understand the divergence of views, partly resting on differing estimates of conceptual difficulties in including caste in the EA, we turn now to the meaning of caste and caste discrimination both in the international context and in the UK. ${ }^{31}$

\section{Explaining Caste and Tracking Caste Discrimination}

The meaning of the term 'caste', the social phenomena it seeks to capture, the processes linked to the perpetuation of caste in one form or another, and the relationship between 'caste', class, and race, continue to be debated in social sciences literature. We agree with the historian Susan Bayly (1999: 6) that 'caste [is] a dynamic and multi-dimensional reality of Indian life, rather than an orientalist fiction or monolithic cultural code.' Diaspora from South Asia have continued to practise some forms of 'caste' behaviour, and it is clear from the existence of the many caste-based organisations in the UK ${ }^{32}$ and from the regular online advertisements for marital partners specifying 'Religion/Caste', (e.g. a Jain/Vania from Ealing or a Hindu/Brahmin from Dundee $)^{33}$ that caste identification is present in the UK. ${ }^{34}$

The Portuguese origin of the term 'caste' from 'casta' (Bayly, 1999: 106; Guha, 2014: 21), which predates the English word 'caste' by more than two centuries, is used by some commentators to challenge its ability to capture Indic forms of social organisation. In our view this challenge fails to appreciate the ways in which the phenomenon of 'caste' has repeatedly adapted so as to redefine and reproduce boundaries between groups (Vishwanath, 2014). Birth-ascribed status is usually accepted as the basis of membership of a bounded group, but this is so only if a person's group membership is acknowledged by others. In the case of the Scheduled Castes and Scheduled Tribes in India, so-named because they are listed by caste/tribe name in Schedules to the COI, certificates issued by the State authorities identify individuals as members of a Scheduled Caste or Tribe (and hence entitled to the benefit of affirmative action measures). In the UK, caste certification does not exist, and no-one advocates adoption of this model, hence recognition of inherited 
caste or tribal status rests either on one's assignment by others to a particular group or subgroup, or on one's own self-definition or self-identification (sometimes through membership of caste-based organisations). Similarly, the practice of endogamy (rules which determine who can or cannot be a marriage partner) reinforces caste identity. Once labelled with a caste/tribal identity, restrictive social interaction, rank ordering of groups, albeit contested, and possible discriminatory behaviour may follow.

The earliest Indian references to caste and its origins appear in the Rg Veda (15000 BCE), the ancient Sanskrit text which represents Hindu society as divided into four varnas or social classes: Brahmin (priests), Kshatriya (warriors, rulers), Vaishya (traders, artisans) and Shudra (labourers). In the South Asian context the term caste also refers to the concept of jati, meaning hereditary-membership of endogamous 'caste' groups, with region-specific hierarchical ordering. The concept of jati is cultural and cross-religious; it is not limited to Hindus. The number of caste groups (jatis) in India is estimated to be anywhere between 2000-4000. Data on caste affiliation in the first three British Indian Censuses $(1865,1872$, 1881) were based on the four-fold Hindu varna division but thereafter shifted away from the religious to the occupational criterion, i.e. caste as essentially guilds, initiated by Census Commissioner Denzil Ibbetson in the 1891 Census (Bannerjee-Dube, 2008: xxxviii) and continued until 1935.

The anthropologist Balmurli Natrajan describes the ways in which 'caste' is normalised and presented as a benign form of cultural grouping when in fact it continues to play a crucial role in the exercise and monopoly of social, political, economic, and cultural power (Natrajan, 2012). In the UK, when victims bring forward claims of harassment, discrimination, or victimization on grounds of caste, understanding the normalisation of casteist patterns of interaction enables us to recognise the common patterns of behaviour used to stigmatise others - looking down on others, attaching prejudicial characteristics to others, treating others as unworthy of an equal moral status, considering others 'unclean', ostracising others if they refuse to follow caste norms, treating others with contempt: these would be some of the ways of recognising caste discrimination.

These 'normalised' patterns of interaction apply to treatment of tribal peoples as well as caste groups, but as pointed out in Dhanda (2014a: 3) 'sociologically speaking, the distinction between caste and tribe is to some extent arbitrary and reified by law'. Tribal peoples in particular were 'primitivized' and infantilized under colonialism (Chandra 2013: 161). However, the 'caste/tribe divide' is not how 'colonial subjects saw themselves'; it was the Scheduled Districts Act 1874 that 'separated castes and tribes by law' (ibid.). The 
arbitrariness of this distinction is crucial to note in the context of the judgment in Tirkey, discussed below.

Dr. Prakash Shah, a legal academic opposed to caste discrimination legislation, has argued that the lack of a single, agreed definition of caste reflects a lack of clarity as to what concepts the English word 'caste' refers to, and that the term has been mapped onto Indian/ South Asian cultural phenomena in a way which only distorts them; for these reasons, he argues, 'caste' cannot and should not be included in the EA (Shah, 2014; Shah, 2015a). However, victims of caste discrimination in the UK have not found the lack of a detailed, agreed definition of 'caste' restrictive in describing the harassment they have had to contend with (Kumar, 1990; ACDA 2009). Interviews with Dalit respondents in the West Midlands, whilst showing a generational difference in the way the old and the young acknowledge, remember, and respond to caste slights (Dhanda, 2014), nonetheless reveal a common factor: they all hope that a change in the law would improve conditions for them.

Caste/tribal status in South Asia is tied to unequal access to resources such as land and water, opportunities such as education and employment, and to political power, as well as acts of humiliation, stigmatisation and, frequently, violence (Thorat and Newman, 2010; Guru, 2009). In the different socio-political environment of the UK, humiliations vary in degree from subtle forms of disrespect and name-calling (e.g. in schools), through to inferiorising of groups, exclusion (e.g. in employment), and refusal of service (DSN, 2006; ACDA, 2009; Metcalf and Rolfe, 2010; Dhanda, 2009, 2015; Ghuman, 2011). The EHRC Caste in Britain reports noted that caste awareness is not necessarily declining or confined to older generations and new cases continue to emerge (Dhanda et al 2014a and 2014b). Some of these cases might be legally actionable under the EA if caste is covered by the legislation, either by explicit inclusion or via judicial interpretation of existing characteristics. But it is important to note that such cases of denigration have the corrosive effect of turning routine confrontations into potentially violent conflicts, ultimately far more risky for the victims of discrimination than the perpetrators, because of the deepening sense of helplessness with every insult that remains unacknowledged as such. In extreme cases, confrontations due to caste divides have led to loss of life, even in the UK. ${ }^{35}$ Unfortunately, there is persistent denial of hidden caste prejudice by some of the so-called upper castes who posit caste identity as a benign ethnic identity, failing to note that, as argued elsewhere, 'carrying the 'caste mark' as a confrontational identity in the face of denigration is different from carrying it as uncritical mark of pride' (Dhanda, 2015: 41). The former may be a necessary strategy of drawing strength from a collective, the latter is the insouciance of the already powerful. 
The difference in the political pressure exerted by competing lobbies on the government of the day might end up determining the direction the law will take. In section 5 below, we discuss the alternatives open to Government in the light of the judgment in Tirkey which was eagerly awaited by all sides in the debate, and which we discuss next.

\section{Case law with special reference to Tirkey $v$ Chandhok \& Anor}

The inclusion of caste within ethnic origins has been argued in three cases. The first, Begraj and Anor v Heer Manak Solicitors and Ors, a pre-EA case, collapsed in February 2013 before judgment was reached, due to judicial recusal. ${ }^{36}$ The first post-EA caste discrimination case in which judgment was reached, Naveed v Aslam and Ors (2012), involved a claim of unlawful racial discrimination on account of caste by a Pakistani restaurant worker against his employers, the owners of an Indian restaurant. The Employment Tribunal (ET) held that the claim of caste discrimination was doomed to failure for two reasons; first, because no order had been made extending EA s. 9(1) so as to provide for caste to amount of itself to an aspect of race; and secondly because it was impossible for the claimant's caste to fall under the existing definition of ethnic origins given that the claimant and respondent were from the 'same' caste (described in the judgment as the 'Arain Pakistani caste'); the ET concluded that the claimant was being treated differently because of his class, not his caste. As explained elsewhere by one of the authors, the ET failed to consider that the Claimant and the Respondents may have been of different subcastes or jatis - and hence of different status - within the wider group or caste to which they both belonged (Waughray, 2014: 17).

The third case, Tirkey $v$ Chandhok and Anor, concerned an Indian domestic servant employed in a private home in the UK. It involved egregious violations of employment rights and unlawful discrimination contrary to the EA which the claimant, Ms. Permila Tirkey, alleged had occurred for reasons related to her ethnic origins including her perceived status in the caste system. There are three judgments in this case: the first, in 2013, followed a preliminary hearing in the ET on an application by the Respondents to strike out the caste element of the Claimant's amended claim (Tribunal 2013); the second, in 2014, was a judgment of the Employment Appeal Tribunal (EAT) on appeal from the ET's refusal to strike out the amendment (Appeal Tribunal 2014); the third was the judgment in the substantive ET hearing in September 2015 (Tribunal 2015). ${ }^{37}$ Ms Tirkey's claim was for unpaid wages, unfair dismissal, violations of the Employment Rights Act 1996 and the Working Time Regulations 1998, direct discrimination or harassment on grounds of race, specifically ethnic origins including her inherited position in society in whole or in part because of her caste, and direct or indirect discrimination on grounds of religion or belief. Ms Tirkey was recruited 
in India by the respondents, Mr and Mrs Chandhok, to work for them as a domestic servant in their UK home. During the four and a half years of her employment Ms Tirkey was subjected to conditions of work and an environment which the ET found violated her dignity and created an atmosphere of degradation (Tribunal 2015, 211). In her evidence Ms Tirkey described her family as "Adivasi" [i.e. tribal] people who are dark skinned and poor', the 'lowest class' in 'the caste pyramid"' (Tribunal 2015, 8). She described herself as a Christian, of the 'servant class', “low caste"', with no employment expectations other than domestic service. This evidence was not challenged by the Chandhoks and was accepted as fact by the Tribunal (Tribunal 2015, 9-10, 24).

In May 2013 - shortly after the introduction of the ERRA requirement that caste must be made an aspect of race in EA s. 9(1) - the claimant was permitted to amend her original claim of race and religious discrimination by inserting a new paragraph averring that "her ethnic and/or national origins includes (sic) but is not limited to her status in the caste system as perceived by the Respondents' (Tribunal 2013, 2; Appeal Tribunal 2014, 6). Her amended claim argued that ICERD prohibits discrimination on grounds of descent, descent has been interpreted by CERD to include caste, the EU Race Directive adopts the principles in ICERD, and the EA implements the Race Directive, therefore the EA should be interpreted as prohibiting caste discrimination. In the new paragraph the claimant averred that 'the and/or a reason why she was recruited and treated in the manner alleged was that the Respondents concluded she was of a lower status to them', and that 'this view was tainted by caste considerations' (Tribunal 2013, 2; Appeal Tribunal 2014, 6). The Respondents denied all the allegations. They applied for the caste discrimination element of the claim to be struck out on the grounds that it had no reasonable prospect of success because - following Naveed - the Tribunal had no jurisdiction to consider it. In a preliminary hearing in December 2013 the ET refused the application. The fact that the government had decided to legislate to make caste an aspect of the protected characteristic of race was not determinative of the issue (Tribunal 2013, 26.5). The ET ruled that EA s. 9(1) 'can and should be construed in such a way as to provide for caste discrimination in the context of this case [emphasis added] to be part of the protected characteristic of race discrimination' (sic) (Tribunal 2013, 26.3). The Respondents appealed. In December 2014 the Honourable Mr Justice Langstaff (President of the EAT), sitting alone, refused the appeal, upheld the ET decision, and referred the case back to the ET. He held that "though "caste" as an autonomous concept did not presently come within the EA s. 9(1) many of the facts relevant in considering caste in many of its forms might be capable of doing so since "ethnic origins" had a wide and flexible ambit including characteristics determined by "descent"', and it was 'possible that the facts found in hearing 
the present claim might come within the scope of that phrase' (Appeal Tribunal 2014, Summary).

Langstaff $P$ noted that the claimant's amendment raised 'no separate claim of caste discrimination as such'; yet it was precisely on the basis that the amendment did raise such a claim that the application to strike it out was pursued (Appeal Tribunal 2014, 7, 8). He identified two central questions; first, whether the predecessor to the EA, the Race Relations Act 1976 (RRA), provided a remedy for discrimination in the factual circumstances which the claimant proposed in her claim to establish in evidence; second, whether, if so, the fact that the EA, as originally enacted and as amended by the ERRA, envisaged the addition of caste to s. 9(1) meant that any claim asserting 'caste' reasons for less favourable treatment was precluded, such that the law no longer provided a remedy for them (Appeal Tribunal 2014, 33). The answer to the first question lay in the principles expressed in the two principal authorities on the scope of race in the RRA, Mandla and JFS, ${ }^{38}$ the effect of which, he found, is to give a wide and flexible scope to the meaning of "ethnic origins" and, given the emphasis on the word "origins" in that phrase, descent is, as JFS shows, clearly to be included within it, at least where it is linked to concepts of ethnicity (Appeal Tribunal 2014, 42). Langstaff $P$ also noted that once a statute is enacted it has the meaning that courts assign to it; Parliament's own view as to that which the legislation meant cannot be conclusive as to its meaning (Appeal Tribunal 2014, 43).

Langstaff $P$ found that the issue of whether "caste" as a distinct concept exists as a separate strand in the definition of race was not determinative; the effect of EA s. 9(5) as amended by the ERRA was to clarify or supplement s. 9(1) (the component elements of race), not to restrict it (Appeal Tribunal 2014, 44, 52). He concluded that there may be factual circumstances in which the application of the label "caste" is appropriate, many of which are capable - depending on their facts - of falling within the scope of s. 9(1), particularly coming within "ethnic origins", as portraying a group with characteristics determined in part by descent, and of a sufficient quality to be described as "ethnic"'(Appeal Tribunal 2014, 51). As a postscript he added that, although the parties may have been hoping for a definitive decision in principle that caste discrimination either was, or was not, within the scope of the $E A$, he did not see his role as being to resolve academic disputes or establish more general propositions; rather, his focus was the appeal in this particular case, in its particular circumstances (Appeal Tribunal 2014, 55).

Judgment in the merits hearing was delivered on 17 September 2015. The ET reiterated the EAT's finding that 'the fact that there is no single definition of caste [as the parties were 
agreed] does not mean that a situation to which that label can, in one of its manifestations, be attached cannot and does not fall within the scope of "ethnic origins"' (Appeal Tribunal 2014, 45; Tribunal 2015, 199). Regarding the race discrimination and/or harassment claim, Ms Tirkey's argument was that her ethnic origins, including her nationality and her hereditary position in society (in whole or in part on the basis of her caste) was the reason she was treated as she was by the Chandhoks.

The extent of the control, exploitation, humiliation, and negation of personal autonomy suffered by Ms Tirkey during the course of her employment with the Chandhoks is evident from the judgment. The Tribunal found that she slept at all times on a mattress on the floor and was not given a bed; she was denied access to her own passport by the Respondents; she had no control over the bank account opened by the Respondents in her name; she worked on an 'on-call' basis seven days per week which meant that she was unable to attend church; her personal freedoms and movement were restricted (for example she was not allowed to go out on her own); she was denied access to English language classes; she had no access to money and was unable to contact her family or to buy clothes or personal effects; she wore second hand clothes not of her choice or taste, provided by the family (Tribunal 2015, 251-253). The Tribunal found that Ms Tirkey was recruited in India to work in the UK because the Respondents wanted someone of Indian descent, whose inherited position was as Ms Tirkey's: 'a low caste, servile, Indian person who could not speak English.' They did not seek a UK-based employee 'because no such person would have accepted the intended conditions of work, either as to physical conditions, workload, or payment/ non-payment' (Tribunal 2015, 205-211).

We argue that the conduct described in the judgment is indicative of the normalized behaviours of humiliation, exploitation, and control typical within relationships of subordination marked by caste and/or tribe difference. ${ }^{39}$ Such extreme behaviour may not be equally evident in other cases of caste and/or tribe discrimination of the kind catalogued in the official and community reports noted above; but the judgment provides valuable insight as to the patterns and types of behaviour through which caste discrimination and harassment are manifested.

\section{Concluding Reflections}

The Government's present position on the duty to make caste an 'aspect of race' in the EA following Tirkey is indicated in its responses to written parliamentary questions in November and December 2015. In the House of Lords on 10 November 2015, in response to a question asking the Government to clarify how the Tirkey judgment has changed the law on 
caste discrimination, the answer was that 'the judgment suggests there is an existing legal remedy for claims of caste-associated discrimination, under the "ethnic origins" element of s.9 EA. ${ }^{40}$ When asked on 14 December 2015 why they had not yet published the 2014 feasibility study on caste discrimination, the Government's written answer on 21 December 2015 was: 'We are currently considering the conclusions and recommendations of the caste feasibility study as part of our wider consideration of the implications of the Tirkey $v$ Chandhok tribunal judgments.' ${ }^{41}$ We suggest that the implications of Tirkey for the addition of caste to the EA are significant but not decisive. In conclusion we explain why we think so.

The ET in Tirkey found, on the basis of the facts, numerous violations of UK employment law by the Chandhoks, moreover that they engaged in unwanted conduct which had the purpose or effect of violating their employee's dignity and creating an intimidating, hostile, degrading or offensive environment for her contrary to the harassment provisions in s. 26 of the EA. ${ }^{42}$ The ET found that this mistreatment was related to Ms Tirkey's race, specifically her ethnic origins, defined as her birth, her descent, her inherited position in society or caste, and her background and upbringing. Rather than seek a UK-based employee who would not have accepted to be treated in the way it was intended to treat Ms Tirkey, the Chandhoks deliberately flouted UK immigration law in order to secure her entry to the UK. ${ }^{43}$ The Chandhoks knew or believed her to be an Adivasi; Scheduled Castes and Scheduled Tribes/Adivasis in India, despite being differently categorised, legally and administratively (a distinction inherited from colonial times - see above), are afforded similar protections by the Constitution of India 1950 and by hate crimes legislation, and share a common experience of inferiorisation, marginalisation, social exclusion, discrimination, and stigmatisation, on the basis of inherited status and hereditary position in society. Ms Tirkey used the term 'caste' to capture this experience, describing herself as both an 'Adivasi' and 'low caste' - descriptions which were not challenged by the Chandhoks. ${ }^{44}$ Both these labels are tied to notions of descent, origins, inherited social position, in other words to the concept of ethnic origins. The key point for the ET was whether, on the evidence, the reason for the mistreatment of Ms Tirkey was related to her ethnic origins, whether actual or as perceived by the Chandhoks. The ET found that it was.

Ms Tirkey's legal representatives declared that the judgment renders untenable the Government's opposition to an explicit statutory prohibition of caste discrimination on the grounds that there is no evidence of such discrimination taking place in the UK. ${ }^{45}$ Dalit Solidarity Network (DSN) UK on its website acknowledged the 'excellent outcome for the victim' but cautioned that 'despite the fact that the judgement appears to allow for caste discrimination under race and ethnic origin, this case does not set a precedent and future 
cases may not be covered by existing legislation.' ${ }^{46}$ Lord Lester QC (Lib Dem) was cited by DSN-UK and by the National Secular Society as stating that the decision is of no value as a precedent and the Government should not be allowed to use it as an excuse for defying the will of parliament. ${ }^{47}$ For the Government, the Minister for Women and Equalities, Nicky Morgan, when asked in the House of Commons by the chairman of the All Party Parliamentary Group for British Hindus, Bob Blackman (Con), shortly after the judgment whether the Government would now undertake not only not to trigger the provision on caste discrimination in the ERRA "but to repeal it so that the Hindu community (sic) will know where it stands legally', responded that because of Tirkey 'the law as it stands has changed'; the judgments in the case 'suggest that legal protection against such discrimination already exists under the Equality Act 2010'. Thus 'a litigant could now seek to bring a case of caste discrimination in an employment tribunal using the ethnic origin provisions in the Equality Act, which is why we should take time to look at the judgment before making further decisions.' 48

The Government has made no comprehensive public statement since Tirkey on the duty to make caste an aspect of race. If it considers Tirkey to establish that discrimination on grounds of caste is covered through judicial interpretation under existing provisions on race, specifically ethnic origins, and that it is therefore unnecessary to make caste an aspect of race in the EA, this could lead to a decision to repeal the statutory duty to add caste to s. 9(1) EA. Alternatively, given the statutory obligation to add caste, the Government could decide that naming caste in some way in s. 9(1) would provide greater clarity than exists under the current EA formulation of race which does not explicitly include caste, thereby 'future-proofing' caste discrimination protection against the development of case law in conflict with Tirkey.

Making caste an aspect of race in the EA would bring other aspects of the legislation into play, for example the public sector equality duty, and the exceptions provisions applicable to community groups and associations. Alternatively, at this stage the government could do nothing and simply allow matters to develop through case law. As a first-tier Tribunal decision, the merits judgment in Tirkey is of persuasive value but has no binding authority as a precedent. However it can only be appealed on a point of law; and the point of law in question here, namely whether ethnic origins in the EA can include caste, was determined by the EAT whose decision preceded the ET hearing and which, as a legally-binding judgment, the ET was obliged to follow. Unless and until the EAT judgment is overruled by a higher court, lower tribunals are obliged to follow it. However, seen through the eyes of potential victims of caste discrimination, a legitimate fear remains that Tirkey may be 
overruled in the future, leaving them potentially unprotected unless and until the position that caste discrimination is covered by the existing prohibition of race discrimination becomes common ground and accepted beyond challenge, or until the position is confirmed by the Supreme Court.

It is our view that even if the precedential value of Tirkey is ultimately limited, the judgment is valuable in addressing the 'problem' of 'no definition' of caste. The lack of an agreed definition of caste has annoyed opponents of caste discrimination legislation for some time (even though neither race nor ethnic origins are defined in statute); however, Langstaff $P$ ruled that the lack of a single definition of caste 'does not mean that a situation to which that label can, in one of its manifestations, be attached cannot and does not fall within the scope of "ethnic origins"' (Appeal Tribunal 2015, 45). Tirkey illustrates that where discrimination is evident or inferable from the facts, the ET will proceed to ask whether the discrimination is related to the relevant protected characteristic - in this case, race, specifically ethnic origins, including notions of inherited status/ and/or caste/ and/or inherited position in society.

However, for the facts to come to light, the claimant has to break out of the silence that is sometimes self-imposed because ill-treatment is a part of normalised conduct. Some victims may feel that this is all someone of their status can expect, and the perpetrator may fail to notice the effect of their exploitative or harassing behaviour. In the case of Ms Tirkey, the exploitative relationship she suffered continued for four and a half years before erupting into a confrontation between her and her employers, and leading to a complaint to the ET which required the support of an NGO, the Anti Trafficking and Labour Exploitation Unit, to come to Tribunal.

From the perspective of victims of caste discrimination, the critical outcome is that such discrimination is acknowledged, recognised, and is prohibited by law. Tirkey $v$ Chandhok has opened up the possibility of bringing claims of caste discrimination in the Employment Tribunal via the interpretive route using ethnic origins in EA s. 9(1)(c), a possibility anticipated in Dhanda et al (2014a: 25). It must be stressed that a significant role in facilitating the outcome in Tirkey was played by the passage of ERRA s. 97 in April 2013 preceded by the inclusion in 2010 of the 'caste power' in EA s. 9, both of which drew on the work of NGOs, parliamentarians and academics in making visible the hidden phenomenon of caste discrimination. It would be premature, even provocative, to repeal EA s. 9(5)(a) on the basis of the judgment in Tirkey, despite pressure from some quarters to do so. For the victims of caste discrimination, such a move would be retrogressive and would be seen as abandoning those who need protection. Extending the EA by secondary legislation, as 
decided by Parliament in April 2013, to include caste as an aspect of race (however this is done), offers legal certainty and proclaims publicly that discrimination on grounds of caste is both unacceptable and unlawful. ${ }^{49}$ Without the EA and the discretionary 'caste power' which was included at the last minute in s. 9(5)(a), and its amendment in 2013 to become a duty, caste might not have been pleaded as a ground of discrimination, or part of one, in Tirkey (or indeed in Naveed). The EA and its amendment have surely increased the traction of caste as a ground of discrimination. However, the unfinished process of embedding protection against caste discrimination within the EA detracts from the otherwise positive assessment of the impact of the EA on this issue five years on.

\section{References:}

ACDA (2009) Hidden Apartheid, Voice of the Community: Caste and Caste Discrimination in the U.K., a scoping study. Derby: Anti-Caste Discrimination Alliance.

Ambedkar B.R. (1917) Castes in India: Their Genesis, Mechanism, and Development. In Rodrigues V. (Ed) The Essential Writings of B.R. Ambedkar. New Delhi: Oxford University Press.

Bayly S. (1999) Caste, Society and Politics in India: from the Eighteenth Century to the Modern Age. Cambridge: Cambridge University Press.

Bannerjee-Dube I. (Ed) (2008) Caste in History. New Delhi: Oxford University Press. Bob C. (2007) Dalit Rights are Human Rights: Caste Discrimination, International Activism, and the Construction of a New Human Rights Issue, Human Rights Quarterly 29 (X):167193.

Chandra U. (2013) Liberalism and Its Other: The Politics of Primitivism in Colonial and Postcolonial Indian Law. Law and Society Review 47 (1): 135 -168.

Dhanda M. (2009) Punjabi dalit youth: Social dynamics of transitions in identity. Contemporary South Asia 17 (1): 47-63.

Dhanda M. (2014) 'Certain Allegiances, Uncertain Identities: The Fraught Struggles of Dalits in Britain'. In Tracing the New Indian Diaspora. Ed. by Om Prakash Dwivedi. New York: Editions Rodopi. pp. 99-119.

Dhanda M. (2015) Anti-Castism and Misplaced Nativism: Mapping caste as an aspect of race. Radical Philosophy, 192: 33-43.

Dhanda M. (2015a) "It is far too late for me, but I would like you to share my experience with the greater community": the silenced conduits of pain. Presented at the international interdisciplinary seminar -'Minds of Caste', 4 September, UCL, London.

https://www.ucl.ac.uk/stream/media/swatch?v=77a6b8d8263e. 
Dhanda M., Waughray A., Keane D., Mosse D., Green, R. and Whittle S. (2014a) $\underline{\text { Caste in }}$ Britain: Socio-legal Review. Equality and Human Rights Commission Research Report no. 91. Manchester: Equality and Human Rights Commission.

Dhanda M., Mosse D., Waughray A., Keane D., Green R., lafrati S. and Mundy J.K. (2014b) Caste in Britain: Experts' Seminar and Stakeholders' Workshop. Equality and Human Rights Commission Research Report no. 92. Manchester: Equality and Human Rights Commission. Ghuman P. (2011) British Untouchable: A Study of Dalit identity and Education. Farnham: Ashgate.

Guha S. (2013) Beyond Caste: Identity and Power in South Asia, Past and Present. Leiden and Boston: Brill.

Guru G. (Ed) (2009) Humiliation. New Delhi: Oxford University Press.

Kumar A. (1990) "I thought I would escape the name, but it has followed me like a dark cloud..." The Daily Telegraph, 11 October, p26.

Lester A. and Bindman G. (1972). Race and Law. Harmondsworth. Penguin Books. Mahimaidass S.L. and Saldana N. (2006) No Escape: Caste Discrimination in the U.K. London: Dalit Solidarity Network (DSN).

Metcalf H. and Rolfe H. (2010) Caste discrimination and harassment in Great Britain. (NIESR Report) London: National Institute of Economic and Social Research.

Mosse D., Dhanda M. and Waughray A. (2014) Negotiating Caste: Public Discourse and Legal Change in the UK. British Association of South Asian Studies Annual conference, Royal Holloway, University of London. 3 April.

Muman S. (2000) Caste in Britain in Dalit Human Rights, Report of the proceedings of an International Conference, London 16-17 September 2000, organized by Voice of Dalit International (VODI) and Dalit Solidarity Network. London: VODI, 10 October, 71-79. Natrajan, B. (2012) The Culturalization of Caste in India: Identity and inequality in a multicultural age. New York: Routledge.

O'Cinneide C. and Liu K. (2015) Defining the limits of discrimination law in the United Kingdom: Principle and pragmatism in tension, International Journal of Discrimination and the Law 15(1-2): 80-100.

Pyper D. (2014) The Equality Act 2010: caste discrimination. House of Commons Briefing Paper No. 06862, 31 December 2014. London: House of Commons Library.

Rao A. (2009) The Caste Question: Dalits and the Politics of Modern India. Berkeley and Los Angeles: University of California Press.

Shah P. (2014) 'UK caste discrimination legislation: Implications for business and employers' 9 October 2014, at https://aryalegal.wordpress.com/2014/10/09/uk-caste-discriminationlegislation-implications-for-business-and-employers/Shah P. (2015a) Why the British government should repeal the caste provision in the Equality Act 2010', 22 July 2015, at 
https://aryalegal.wordpress.com/2015/07/22/why-the-british-government-should-repeal-thecaste-provision-in-the-equality-act-2010/

Shah P. (2015b) 'What's caste got to do with it? Deception and the law on caste

discrimination', 30 September 2015, at https://aryalegal.wordpress.com/2015/09/30/whats-

caste-got-to-do-with-it-deception-and-the-law-on-caste-discrimination/

Thorat S. and Newman K. (eds) (2010) Blocked by Caste: Economic Discrimination in

Modern India. Delhi: Oxford University Press.

Vishwanath R. (2014) The Pariah Problem: Caste, Religion, and the Social in Modern India.

New York: Columbia University Press.

Waughray A. (2009) Caste discrimination: A Twenty-first century challenge for UK

discrimination law? Modern Law Review 72 (2): 182-219.

Waughray A. (2013) Capturing Caste in Law: The Legal Regulation of Caste and Caste-

based Discrimination. Unpublished PhD thesis, University of Liverpool Repository, University of Liverpool.

Waughray A. (2014) Capturing Caste in Law: Caste Discrimination and the Equality Act 2010 Human Rights Law Review 14 (2): 359-379.

Zaffrelot C. (2005) Dr. Ambedkar and Untouchability: Analysing and Fighting Caste. London: Hurst \& Company.

\footnotetext{
* Annapurna Waughray is Reader in Human Rights Law at Manchester Metropolitan University. Meena Dhanda is Reader in Philosophy and Cultural Politics at University of Wolverhampton. Contact emails: a.waughray@mmu.ac.uk; m.dhanda@wlv.ac.uk.

${ }^{1}$ See Waughray (2014).

${ }^{2}$ See https://www.gov.uk/government/publications/caste-discrimination-legislation-timetable (visited 29 December 2015). See also HC Deb vol 584 col 134WH-142WH 9 Jul 2014; HL vol 755 col WA357-358.

${ }^{3}$ See HC Deb vol 584 col 141WH 9 Jul 2014.

${ }^{4}$ Feasibility study on measuring caste discrimination in Britain was commissioned by the Government Equalities Office (GEO) to Tns-BMRB and the National Institute of Economic and Social Research in 2014 to explore methodological and technical issues (including possible ethical ones) and the costs associated with reliably and accurately measuring caste discrimination over time. One of the authors, Dhanda, was consulted on ethical issues.

${ }^{5}$ See also Letter, Helen Grant (Minister for Women and equalities) to the AHO, 9 May 2013, at http://www.mycasteishindu.org/images/pdfs/Helen_Grant_Letter to AHO.pdf (visited 14 September 2015).

${ }^{6}$ Naveed $v$ Aslam and others ET /1603968/2011.

${ }^{7}$ Tirkey v Chandhok and Anor [2015] ET/3400174/2013 (Tribunal 2015), paras. 2, 205-210.

${ }^{8}$ See http://www.bbc.co.uk/news/uk-34330986 (visited 22 September 2015).

${ }^{9}$ The term 'Dharmic communities' is explained by Prakash Shah as follows: '[A]n umbrella term..... consisting of people who follow any of the Indian traditions that often brought under the labels Hinduism, Jainism, Sikhism, or Buddhism (sic). The choice of term reflects the importance of the idea of Dharma/Dhamma shared by these traditions, which we believe also underpins the open-ended pluralism of Indic civilization which requires adherence to no specific belief system or dogma'; see "EHRC Strategic Plan 2016-2019 Consultation: UK Dharmic Communities' Response" at https://aryalegal.wordpress.com/2015/12/18/ehrc-strategic-plan-20162019-consultation-uk-dharmic-communities-response/ (visited 21 December 2015).
} 
${ }^{10}$ For a response to the charge made by Shah (2014) that the 'caste system' was a creation of 'Christian conversion efforts' see Dhanda (2015).

${ }^{11}$ For a fuller account see Dhanda et al. (2014a: 27-34); Waughray (2014).

${ }^{12}$ The term 'Dalit' means 'crushed' or 'broken to pieces'(Rao, 2009: 1)

${ }^{13}$ The term 'caste' appeared in British India legislation e.g. in the Caste Disabilities Removal Act 1850 which abolished the imposition of penalties under religious law with regards to inheritance and other matters when a person converted out of Hinduism.

${ }^{14}$ Constitution of India (COI) Article 15; see http://india.gov.in/my-government/constitution-india (visited 18 October 2015).

${ }^{15}$ COI Article 17, ibid.

${ }^{16}$ COI Article 16, ibid.

${ }^{17}$ See Protection of Civil Rights Act 1955 at http://ncsc.nic.in/files/PCR_ACT1955.pdf ; Scheduled Castes and Scheduled Tribes (Prevention of Atrocities) Act 1989 at http://socialjustice.nic.in/poa-act.php (both visited 18 October 2015).

${ }^{18}$ UN Doc. CERD/C/304/Add.13, 17 September 1996.

${ }^{19}$ Committee for the Elimination of Racial Discrimination, General Recommendation No. 29 on Article 1(1) of the Convention (Descent).

${ }^{20}$ UN Sub-Commission, Resolution 2000/4, Discrimination based on work and descent (DWD), 11 August 2000; UN Doc. E/CN.4/Sub.2/2000/46, 23 November 2000, 25; R.K.W. Goonesekere, Working paper on the topic of discrimination based on work and descent; UN Doc. E/CN.4/ Sub.2/2001/16, 14 June 2001.

${ }^{21}$ Waughray (2013), Chapter 6.

${ }^{22}$ See Waughray (2013) Chapters 6 and 9. See also Waughray (2009: 203-206). On how uncritical multiculturalism naturalises difference as pre-given and denies difference within difference see Dhanda (2015).

${ }^{23}$ See for example Castewatch UK Archives at http://castewatchuk.org/archives/castewatch-orig/history.htm; Castewatch UK Sandwell conference http://castewatchuk.org/archives/castewatch-orig/sandwellconference.htm; Castewatch UK Westminster conference http://www.castewatchuk.org/westminster-conference.htm (all visited 29 December 2015).

${ }^{24}$ Mandla (Sewa Singh) and Anor v Dowell Lee and Ors [1983] 1 All ER 1062, 1066-1067.

${ }^{25}$ Rastafarians and Muslims are now covered by provisions on religious discrimination.

${ }^{26}$ See Waughray (2009); Castewatch UK Westminster conference, $\mathrm{n} 23$ above.

${ }^{27} R$ (on the application of E) (Respondent) $v$ The Governing Body of JFS and the Admissions Appeal Panel of

JFS and others (Appellant) [2009] UKSC 15; see also Waughray (2014).

${ }^{28}$ See for example Vera Baird QC, HC Deb vol 508 col 9286 April 2010.

${ }^{29} \mathrm{See}$ http://www.hinducouncil.net/index.php/news-and-media/news-letters/85-caste-discrimination-andharassment-in-great-britain (Posted on 24 August 2011; visited 29 December 2015).

30 See http://www.mycasteishindu.org/index.php/component/content/article/20-frontpage/318-press-release13th-november-2013 (visited 29 December 2015).

${ }^{31}$ An analysis of different community positions on the desirability of including 'caste' in the EA, following the EHRC project, was presented in Mosse, Dhanda and Waughray (2014), forthcoming.

${ }^{32}$ There are many caste based organisations in the UK e.g. Ramgarhia Gurdwara Society of Hitchin, Gujrati Arya Association, Shree Kshatriya Association of UK, and East London and Essex Brahm Samaj. One active and unique caste-based organisation is Registered Charity no. 288167, Navnat Vanik Association of the United Kingdom. In a history of this community, Jayant Doshi writes: 'I realised that the caste system, the customs and traditions are so entwined in our lives that it would be difficult to discard them over night. I realised that the caste based social organisation would be required in our lives for many years to come'; see http://www.navnat.com/pages.php?page=history (visited 11 Oct 2015).

${ }^{33}$ These are current advertisements on http://www.shaadi.com/matrimony/gujarati-matrimony (visited 11 Oct 2015).

${ }^{34}$ We have explained elsewhere that the continued existence of caste based organisations would be covered by the EA exceptions provisions for associations in the same way as associations based on other aspects of race (except colour) (Dhanda et al. 2014a: 24).

${ }^{35}$ For a painful case of a young British Punjabi man driven to commit suicide due to the recalcitrant caste divide that jeopardised his plans to marry the woman he loved, see Dhanda, M. (2015a).

${ }^{36}$ See Begraj and another (appellants) v Heer Manak Solicitors and others (respondents), [2014] Industrial Relations Law Reports 689-696.

${ }^{37}$ Tirkey v Chandhok and Anor ET/3400174/2013 (Tribunal 2013); Chandhok and Anor v Tirkey [2014] UKEAT/0190/14/KN (Appeal Tribunal 2014); Tirkey $v$ Chandhok and Anor [2015] ET/3400174/2013 (Tribunal 2015).

${ }^{38}$ See $\mathrm{n} 24$ and n 27, above. 
${ }^{39}$ One of the authors, Dhanda, observed the hearing as a member of the public. In the demeanour of the Chandhoks there was no sense of apology for mistreatment of Ms Tirkey. Rather, the Respondents claimed they had treated her like a 'member of the family'.

${ }^{40}$ HL Deb vol 766 no 18 HL 318010 November 2015.

${ }^{41}$ HL Deb vol 766 no 41 HL 454721 December 2015.

${ }^{42}$ It was suggested in 2009 that the new EA harassment provisions offered 'an as yet unexplored remedy to casteist bullying occurring in regulated fields' (Waughray, 2009: 203).

${ }^{43}$ The judgment does not justify the assertion by one commentator that 'it was simply assumed throughout that, because the claimant was an Adivasi and the employers were from an upper caste, caste discrimination must have been present' (Shah, 2015b).

${ }^{44}$ We reject the argument (see Shah, ibid.) that because of their separate administrative and legal status in India, Adivasis are not subjected to behaviour which can be described as casteist.

${ }^{45}$ See "Victim of Domestic Servitude wins first caste discrimination claim in the Employment Tribunal", Press Release, 21 September 2015, Anti Trafficking and Labour Exploitation Unit, at http://atleu.org.uk/our-recentcases/2015/9/21/victim-of-domestic-servitude-wins-first-caste-discrimination-claim (visited 18 October 2015).

${ }^{46}$ See http://dsnuk.org/2015/09/23/tirkey-v-chandok-case-rules-in-favour-of-the-victim//visited 18 October 2015).

47 See http://www.secularism.org.uk/news/2015/09/calls-for-government-to-outlaw-caste-discrimination-aftertribunal-rules-in-favour-of-victim-kept-in-domestic-servitude (visited 18 October 2015).

${ }^{48} \mathrm{HC}$ Deb vol 600 col 47915 Oct 2015.

${ }^{49}$ The process of instituting the pending secondary order would also provide an opportunity to revisit and refine the Explanatory Notes on caste in line with suggestions since the enactment of the EA. 